\title{
Current and residual effects of compost and inorganic fertilizer on wheat and soil chemical properties
}

\author{
Nigus Demelash • Wondimu Bayu • \\ Sitot Tesfaye $\cdot$ Feras Ziadat $\cdot$ Rolf Sommer
}

Received: 4 April 2014/Accepted: 6 November 2014/Published online: 13 November 2014

(C) Springer Science+Business Media Dordrecht 2014

\begin{abstract}
Restoring soil fertility in smallholder farming systems is essential to sustain crop production. An experiment was conducted in 2011 and 2012 to study the effect of compost and inorganic fertilizer application on soil chemical properties and wheat yield in northwest Ethiopia. Full factorial combinations of four levels of compost $\left(0,4,6,8 \mathrm{tha}^{-1}\right)$ and three levels of inorganic fertilizers $(0-0,17.3-5$, $34.5-10 \mathrm{~kg} \mathrm{~N}-\mathrm{P} \mathrm{ha}{ }^{-1}$ ) were compared in a randomized complete block design with three replications. In 2012, two sets of trials were conducted: one was the repetition of the 2011 experiment on a new experimental plot and the second was a residual effect study conducted on the experimental plots of 2011. Results
\end{abstract}

N. Demelash

Gondar Agricultural Research Centre,

P.O.Box 1337, Gondar, Ethiopia

W. Bayu ( $\square)$

International Center for Agricultural Research in the Dry

Areas, P.O.Box 527, Bahir Dar, Ethiopia

e-mail: wondimubayu@yahoo.com

S. Tesfaye

Wello University, P.O.Box 1145, Desse, Ethiopia

F. Ziadat

International Center for Agricultural Research in the Dry

Areas, Amman, Jordan

R. Sommer

International Center for Tropical Agriculture, Nairobi, Kenya showed that in the year of application, applying $6 \mathrm{t}$ compost ha ${ }^{-1}$ with $34.5-10 \mathrm{~kg} \mathrm{~N}-\mathrm{P}$ ha ${ }^{-1}$ gave the highest significant grain yield. In the residual effect trial, $8 \mathrm{t}$ compost $\mathrm{ha}^{-1}$ with $34.5-10 \mathrm{~kg} \mathrm{~N}-\mathrm{P} \mathrm{ha}^{-1}$ gave $271 \%$ increase over the control. Grain protein content increased 21 and $16 \%$ in the current and residual effect trials, respectively, when $8 \mathrm{t}$ compost ha $^{-1}$ was applied; it increased 11 and $14 \%$ in the current and residual effect trials, respectively, when $34.5-10 \mathrm{~kg} \mathrm{~N}-\mathrm{P}$ ha $^{-1}$ was applied. Under the current and residual effects of $8 \mathrm{t}$ compost $\mathrm{ha}^{-1}$, SOM increased 108 and $104 \%$; available $\mathrm{P} 162$ and $173 \%$; exchangeable $\mathrm{Ca} 16.7$ and $17.4 \%$; and CEC 15.4 and $17.1 \%$, respectively. Applying $6 \mathrm{t}$ compost $\mathrm{ha}^{-1}$ with $34.5-10 \mathrm{~kg} \mathrm{~N}-\mathrm{P} \mathrm{ha}^{-1}$ is economically profitable with $844 \%$ MRR.

Keywords Soil fertility · Organic matter · Grain protein · Vertisol

\section{Introduction}

Poor soil fertility as a result of unsustainable agricultural practices is one of the major threats to agricultural productivity and food security in the smallholder farming systems in Sub Saharan Africa (Sanchez and Leakey 1997). Agricultural productivity and food security in Sub Saharan Africa (SSA) are seriously jeopardized by the steady decline in soil fertility, 
defined as "a net decrease in available nutrients and organic matter in the soil" (Voortman et al. 2000). Continuous and intensive cropping without any effort to restore soil fertility has depleted the nutrient base of most soils (Bationo et al. 1998). Increasing population pressure on agricultural land has resulted in higher nutrient outflows thus creating a vicious circle of food insecurity and poverty (Sanchez et al. 1997). The need to tackle soil fertility depletion is thus a fundamental biophysical constraint to ensure food security in Africa (Sanchez and Leakey 1997).

It is well recognized that soil organic matter plays a major role in soil fertility by affecting physical and chemical properties, and also controling soil microbial activity by serving as a source of mineralizable carbon (C) and N (Solomon et al. 2002). Thus, productivity losses in many of the SSA countries are often attributed to loss of soil organic carbon and accelerated water depletion resulting from severe soil degradation (Lakew et al. 2000). Complete residue removal for fodder and fuel, and intensive and excessive tillage have depleted soil organic $\mathrm{C}$ stocks which has led to the deterioration of soil fertility and soil water storage capacity, resulting in frequent crop failures. Degraded soils commonly reduce payoffs to agricultural investment as they rarely respond to external inputs, such as mineral fertilizers, and hence reduce the fertilizer use efficiency and return on investment (Tilahun 2003). Such soils also have very poor water holding capacity, partly because of low soil organic matter content, which in turn reduce fertilizer use efficiency (Tilahun 2003). Overexploitation of land resources without returning the basic nutrients to the soil is an important factor that contributes most to poor productivity (Bationo et al. 2007).

In the highlands of Ethiopia in general, and the Amhara region in particular declining soil fertility is also immensely constraining to agricultural productivity (Lakew et al. 2000). Even though the farming system in the highlands of Amhara region is a mixed crop-livestock system, nutrient flows between the two system's components are predominantly one way, with feeding of crop residues to livestock but little or no dung and residue being returned to the soil. Estimates of soil nutrient loss in Ethiopia between 1982 and 1984 show a net removal of $41 \mathrm{~kg} \mathrm{~N} \mathrm{ha}^{-1}$ from agricultural land, and losses for the year 2000 were projected to reach $47 \mathrm{~kg} \mathrm{~N}^{-1}$ (Stoorvogel et al. 1993). Currently, the situation would be worsened with the ongoing intensive cultivation without due regard to restoring soil organic matter content. Therefore, if agricultural productivity in the smallholder farming is to be improved and food security granted, emphasis should be given to replenishing the soil fertility. On the other hand, although substantial crop yields can be achieved through applying inorganic fertilizers, most smallholder farmers in the Amhara region rarely use them because of high cost and low and variable returns. These soils can no longer be productive with the existing fertility status and if the trend of low inorganic fertilizer use continues, alternative soil fertility management strategies need to be sought. Therefore, an integrated nutrient management approach which acknowledges the need for both organic and inorganic mineral inputs is promoted due to positive interactions and complementarities between them (Abedi et al. 2010). Thus, adopting this strategy should increase crop productivity, prevent soil degradation, enhance carbon storage in the soil and also reduce emissions from nitrogen fertilizer use and thereby help meet future food supply needs. Compost has strong carryover effect, however, the short term benefits of infrequent application to yield and soil qualities in Vertisols have not been evaluated in the watershed. This study was, therefore, conducted at on-farm to evaluate the current and residual effects of different levels of compost and inorganic fertilizer application on wheat grain yield and chemical properties of the soil in the GumaraMaksegnit watershed.

\section{Materials and methods}

\section{Description of the study area}

The study was conducted on a farmers' field in the Gumara-Maksegnit watershed in northwest Ethiopia. The watershed is located between $120^{\circ} 23^{\prime} 53^{\prime \prime}$ to $120^{\circ} 30^{\prime} 49^{\prime \prime}$ latitude and $370^{\circ} 33^{\prime} 39^{\prime \prime}$ to $370^{\circ} 37^{\prime} 14^{\prime \prime}$ longitude and an altitude of $1,953 \mathrm{~m}$ above sea level. The soil at the experimental site is classified as Vertisol. The long term average annual rainfall is $\approx 1,052 \mathrm{~mm}$. The mean minimum and maximum temperatures of the area are 13.3 and $28.5^{\circ} \mathrm{C}$, respectively (NMSA 2009). The soil had a clay texture with $53 \%$ clay, $19 \%$ silt and $28 \%$ sand contents. The $0-40 \mathrm{~cm}$ horizon has on average a pH of 7.5 (1:2.5 in 
Table 1 Chemical properties of the compost used in the field experiments

\begin{tabular}{lc}
\hline Chemical properties & Values \\
\hline $\mathrm{pH}$ & 6.46 \\
Available P $\left(\mathrm{mg} \mathrm{kg}^{-1}\right)$ & 47.73 \\
Organic matter $(\%)$ & 5.74 \\
$C E C\left(\mathrm{cmol}^{(+)} \mathrm{kg}^{-1}\right)$ & 105.0 \\
Exchangeable $\mathrm{Ca}\left(\mathrm{cmol}^{(+)} \mathrm{kg}^{-1}\right)$ & 50.29 \\
Exchangeable $\mathrm{Mg}\left(\mathrm{cmol}^{(+)} \mathrm{kg}^{-1}\right)$ & 14.63 \\
Exchangeable $\mathrm{K}\left(\mathrm{cmol}^{(+)} \mathrm{kg}^{-1}\right)$ & 1.2 \\
Exchangeable $\mathrm{Na}\left(\mathrm{cmol}^{(+)} \mathrm{kg}^{-1}\right)$ & 0.83 \\
\hline
\end{tabular}

water), $3.96 \%$ organic matter, $0.19 \%$ total $\mathrm{N}$, $6.4 \mathrm{mg} \mathrm{kg}^{-1}$ available (Olsen) $\mathrm{P}, 2.16 \mathrm{cmol}^{(+)} \mathrm{kg}^{-1} \mathrm{~K}$, $38.31 \mathrm{cmol}^{(+)} \mathrm{kg}^{-1} \mathrm{Ca}, 12.09 \mathrm{cmol}^{(+)} \mathrm{kg}^{-1} \mathrm{Mg}, 0.38$ $\mathrm{cmol}^{(+)} \mathrm{kg}^{-1} \mathrm{Na}$, and cation exchange capacity (CEC) of $58.40 \mathrm{cmol}^{(+)} \mathrm{kg}^{-1}$.

Experimental design and procedures

The study was conducted in 2011 and 2012. In 2012, two sets of trials were conducted: one is the repetition of the 2011 experiment on a new experimental plot and the second is a residual effect study conducted on the experimental plots of 2011. Treatments comprised factorial combinations of four levels of compost, 0,4 , 6 , and $8 \mathrm{tha}^{-1}$ on dry weight basis, and three levels of inorganic fertilizer combinations, $0-0,17.3-5$, $34.5-10 \mathrm{~kg} \mathrm{~N}-\mathrm{P} \mathrm{ha}^{-1}$. The fertilizer combinations are 0,25 , and $50 \%$ of the recommended $69 \mathrm{~kg} \mathrm{~N} \mathrm{ha}^{-1}$ and $20 \mathrm{~kg} \mathrm{P} \mathrm{ha}^{-1}$ fertilizer rates, respectively. The experimental design was a randomized complete block with three replications. A compost prepared through heap method out of $40 \%$ cactus and crop residue, $10 \%$ vegetable and fruit peels (avocado, mango and vegetable skins), $20 \%$ animal manure, $10 \%$ ash, $5 \%$ soil, and $15 \%$ cattle urine was applied on dry weight basis, spread evenly, and incorporated into the top $10 \mathrm{~cm}$ soil layer 2 weeks before planting. The chemical properties of the compost used for the study are presented in Table 1. The application of 4, 6 and $8 \mathrm{t}$ compost ha ${ }^{-1}$ implies addition of $0.19,0.29$, and $0.38 \mathrm{~kg}$ available $\mathrm{P} \mathrm{ha}^{-1}$; 40,60 , and $80 \mathrm{~kg}$ exchangeable $\mathrm{Ca} \mathrm{ha}^{-1} ; 7,10.5$, and $14 \mathrm{~kg}$ exchangeable $\mathrm{Mg} \mathrm{ha}^{-1} ; 1.9,2.8$, and $3.7 \mathrm{~kg}$ exchangeable $\mathrm{K} \mathrm{ha}^{-1}$; and $0.8,1.1$, and $1.5 \mathrm{~kg}$ exchangeable $\mathrm{Na} \mathrm{ha}^{-1}$. Urea and Di-ammonium phosphate (DAP) were used as inorganic fertilizer sources. Half of the urea and all the DAP were applied in rows at planting and incorporated into the soil. The remainder of the urea was side dressed at tillering. Bread wheat var. Kubsa and var. Tay were planted in 2011 and 2012, respectively, in rows at the seed rate of $125 \mathrm{~kg} \mathrm{ha}^{-1}$. Planting was made on broad bed and furrows to facilitate water drainage. Gross and net plot sizes were $6 \mathrm{~m} \times 6 \mathrm{~m}$ and $5 \mathrm{~m} \times 5 \mathrm{~m}$, respectively. Weeds were removed manually as needed. No insecticide or fungicide was applied as there was no serious incidence of insect pests or diseases.

Prior to planting, composite surface $(0-40 \mathrm{~cm})$ soil samples were collected from five points across the experimental field and analyzed for soil chemical properties. Composite soil samples from the $0-25 \mathrm{~cm}$ depth at three points were collected from each plot 15 days after compost application and the composite sample analyzed for soil chemical properties. Similarly, for the residual effect study, soil samples from $0-25 \mathrm{~cm}$ depth were collected from three points at each plot just before planting and analyzed for soil chemical contents. Soil samples were mixed, homogenized, air dried in shade, ground and passed through a $2 \mathrm{~mm}$ sieve, and analyzed for total $\mathrm{N}$, available $\mathrm{P}, \mathrm{pH}$, organic carbon, exchangeable cations $\left(\mathrm{Na}^{+}, \mathrm{K}^{+}, \mathrm{Ca}^{2+}, \mathrm{Mg}^{2+}\right)$ and $C E C$. Soil texture was determined using Bouyoucos hydrometer method (Tisdale et al. 1993). Available P was extracted with sodium bicarbonate solution at $\mathrm{pH} 8.5$ following the procedure described by Olsen et al. (1954). Total nitrogen was determined by the micro-Kjeldahl digestion, distillation and titration method as described by Jackson (1958). Soil pH was measured potentiometrically in the supernatant suspension of a 1:2.5 soil:water mixture using a $\mathrm{pH}$ meter according to method outlined by Sahlemedhin and Taye (2000). Organic carbon was determined following the Walkley and Black wet oxidation method as described by Jackson (1958). The soil CEC was determined at $\mathrm{pH} 7$ after displacement of the cations by using $1 \mathrm{~N}$ ammonium acetate; thereafter, the ammonium was estimated titrimetrically by distillation of ammonium that was displaced by sodium following the procedure of Sahlemedhin and Taye (2000). Total exchangeable bases were determined after leaching the soils with ammonium acetate; $\mathrm{Ca}^{2+}$ and $\mathrm{Mg}^{2+}$ in the leachate were analyzed by atomic absorption spectrophotometer and $\mathrm{K}^{+}$and $\mathrm{Na}^{+}$were analyzed flame photometrically following the procedure of Sahlemedhin and Taye (2000). 
Data on grain and straw yields, grain protein content and soil chemical properties were collected. Grain protein content was determined using near infrared reflectance spectroscopy (NIRS). Analyses of variance (ANOVA) for all data were performed using the SAS statistical program (SAS V9.0, SAS Institute Inc., Cary, NC, USA). Whenever the ANOVA detected significant differences between treatments, mean separation was conducted using least significant difference (LSD). Economic analysis was performed following the CIMMYT partial budget methodology (CIMMYT 1988). Average wheat grain price of US $\$ 0.45 \mathrm{~kg}^{-1}$ and straw price of US $\$ 1.05 \mathrm{t}^{-1}$ were considered for the analysis. The prices of DAP, urea and compost were US\$0.78 kg $\mathrm{kg}^{-1}$ US $\$ 0.65 \mathrm{~kg}^{-1}$, and US $\$ 14.47 \mathrm{t}^{-1}$, respectively. To apply 4,6 , and $8 \mathrm{t}$ compost ha ${ }^{-1}$, two, three and four man-days, respectively were needed. The labour cost for compost application was US\$1.58 per man-day. Following CIMMYT's partial budget analysis methodology, total variable costs (TVC), gross benefit and net benefit were calculated. Total variable cost was calculated as the sum of cost of urea, cost of DAP, cost of compost and cost of labor to apply compost. Net benefit was calculated as the difference between gross benefit and the TVC. Grain and straw yields were adjusted downwards by $10 \%$ assuming that farmers will obtain yields $10 \%$ lower than obtained by researchers. Then treatments were listed in order of increasing total costs that vary and dominance analysis was performed where dominated treatments were eliminated and the marginal rate of return (MRR) calculated for the remaining treatments. A treatment that has net benefits that are less than or equal to those of a treatment with lower costs that vary is dominated. A treatment which is non-dominated and having a MRR of greater or equal to $100 \%$ and the highest net benefit is considered to be economically profitable.

\section{Results}

Grain and straw yield

Both in the current and residual effects grain yield was significantly affected by the direct and the interaction effect of the combined use of compost and inorganic fertilizers (Table 2).
In the current effect, the highest significant grain yield was obtained applying $6 \mathrm{t}$ compost $\mathrm{ha}^{-1}$ with $34.5-10 \mathrm{~kg} \mathrm{~N}-\mathrm{P}$ ha $^{-1}$ followed by applying $8 \mathrm{t}$ compost ha ${ }^{-1}$ with $34.5-10 \mathrm{~kg} \mathrm{~N}-\mathrm{P} \mathrm{ha}{ }^{-1}$ (Fig. 1). Applying compost alone also has significantly increased grain yield with a yield benefit ranging from 151 to $351 \%$. Across all the N-P levels grain yield has significantly increased with an increase in the compost rate. In the residual effect, the highest significant grain yield was obtained from $8 \mathrm{t}$ compost ha ${ }^{-1}$ with $34.5-10 \mathrm{~kg} \mathrm{~N}-\mathrm{P}$ ha $^{-1}$ applied in the preceding season (Fig. 1).

Both in the current and residual effects, straw yield responded only to the main treatment effects of compost and inorganic fertilizers, but not to the interaction effect. Averaged over all N-P fertilizer levels, straw yield increased with an increase in compost rate, with the highest significant straw yield recorded with the application of $8 \mathrm{t}$ compost $\mathrm{ha}^{-1}$ (Fig. 2a). With regard to response to inorganic fertilizers, both in the current and residual effects, averaged over all compost levels straw yield was significantly higher with the application of $34.5-10 \mathrm{~kg} \mathrm{~N}-\mathrm{P}$ ha $^{-1}$ (Fig. 2b). Straw yield in the residual plots was generally low compared to the current application.

\section{Grain protein content}

Grain protein content responded to the main effects of compost and inorganic fertilizers, but not to the interaction effect (Table 2). Averaged over the levels of N-P fertilizers, grain protein content increased following the current as well as the residual increase in compost rate. Significantly higher grain protein content was recorded at $8 \mathrm{t}$ compost $\mathrm{ha}^{-1}$ (Fig. 3a). Averaged over the levels of compost, grain protein content was significantly higher with the application of 34.5-10 kg N-P ha ${ }^{-1}$ (Fig. 3b).

\section{Soil chemical properties}

In both the current and residual effects, when averaged over the N-P rates compost application significantly increased available $\mathrm{P}$, organic matter, exchangeable Ca contents and CEC of the soil (Fig. 4). Nevertheless, compost application did not have significant effect on soil $\mathrm{pH}$ and on exchangeable $\mathrm{Mg}, \mathrm{K}$ and $\mathrm{Na}$ contents. Applying $8 \mathrm{t}$ compost $\mathrm{ha}^{-1}$ in the current trial, and 4, 6 
Table 2 Analysis of variance for the effect of compost and inorganic fertilizers on grain yield, straw yield and grain protein content (GPC) of bread wheat, in the Gumara-Maksegnit watershed

\begin{tabular}{|c|c|c|c|c|c|c|c|}
\hline \multirow[t]{2}{*}{ Source of variation } & \multirow{2}{*}{ df } & \multicolumn{3}{|l|}{ Current } & \multicolumn{3}{|l|}{ Residual } \\
\hline & & Grain yield & Straw yield & GPC & Grain yield & Straw yield & GPC \\
\hline Compost (C) & 3 & $1,276,765.05 * *$ & $4,760,653.44 * *$ & $8.92 * *$ & $1,201,952.6 * *$ & $2,503,855.4 * *$ & $8.3 * *$ \\
\hline Inorganic fertilizer $(\mathrm{F})$ & 2 & $3,872,445.98 * *$ & $7,201,779.07 * *$ & $6.04 * *$ & $3,084,720.2 * *$ & $5,391,588.4 * *$ & $7.6 * *$ \\
\hline $\mathrm{C} \times \mathrm{F}$ & 6 & $2,434,768.83^{* *}$ & $1,181,063.74 \mathrm{~ns}$ & $0.63 \mathrm{~ns}$ & $67,796.1 * *$ & $1,097,806.4 .74 \mathrm{~ns}$ & $0.63 \mathrm{~ns}$ \\
\hline Error & 24 & $42,637.71$ & $980,580.57$ & 0.42 & $42,131.7$ & $334,585.1$ & 0.48 \\
\hline
\end{tabular}

** and ns denote significant difference at $P \leq 0.01$ and non-significant difference, respectively

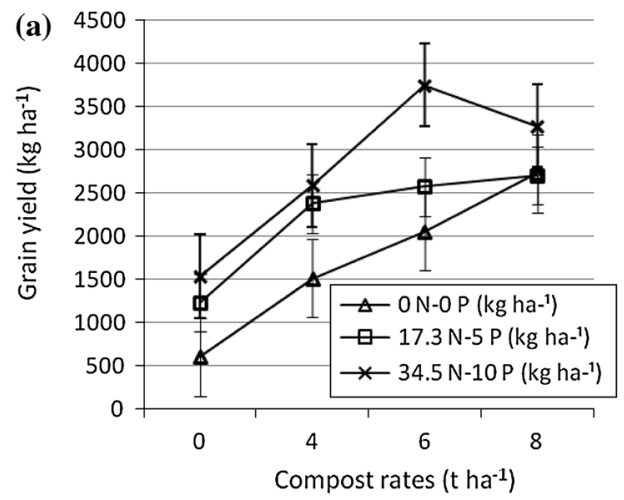

(b)

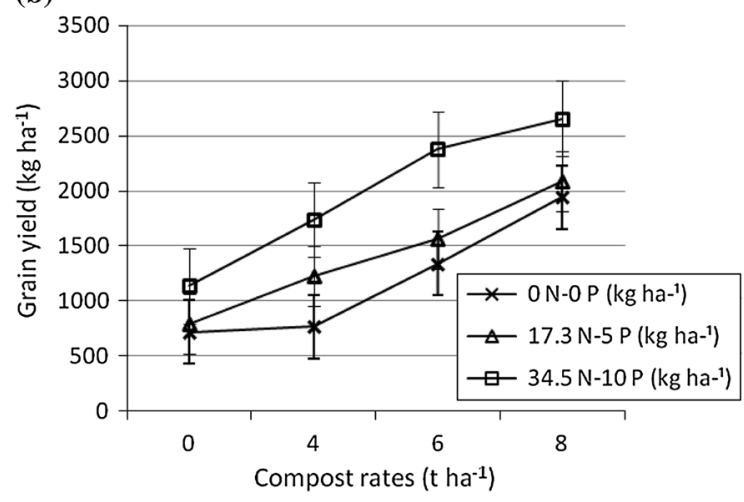

Fig. 1 Current (a) and residual (b) effects of compost and inorganic fertilizers on mean wheat grain yield, at the GumaraMaksegnit watershed. Vertical bars represent $\pm \mathrm{SE}$

and $8 \mathrm{t}$ compost ha ${ }^{-1}$ in the residual effect trial gave significantly higher available P (Fig. 4a). Organic matter content was significantly higher for 4, 6 and $8 \mathrm{t}$ compost ha ${ }^{-1}$ both in the current and residual effects trials (Fig. 4b). Exchangeable Ca content was significantly higher in the current trial when applying 6 and $8 \mathrm{t}$ compost ha $\mathrm{h}^{-1}$, and $8 \mathrm{t}$ compost ha ${ }^{-1}$ in the residual
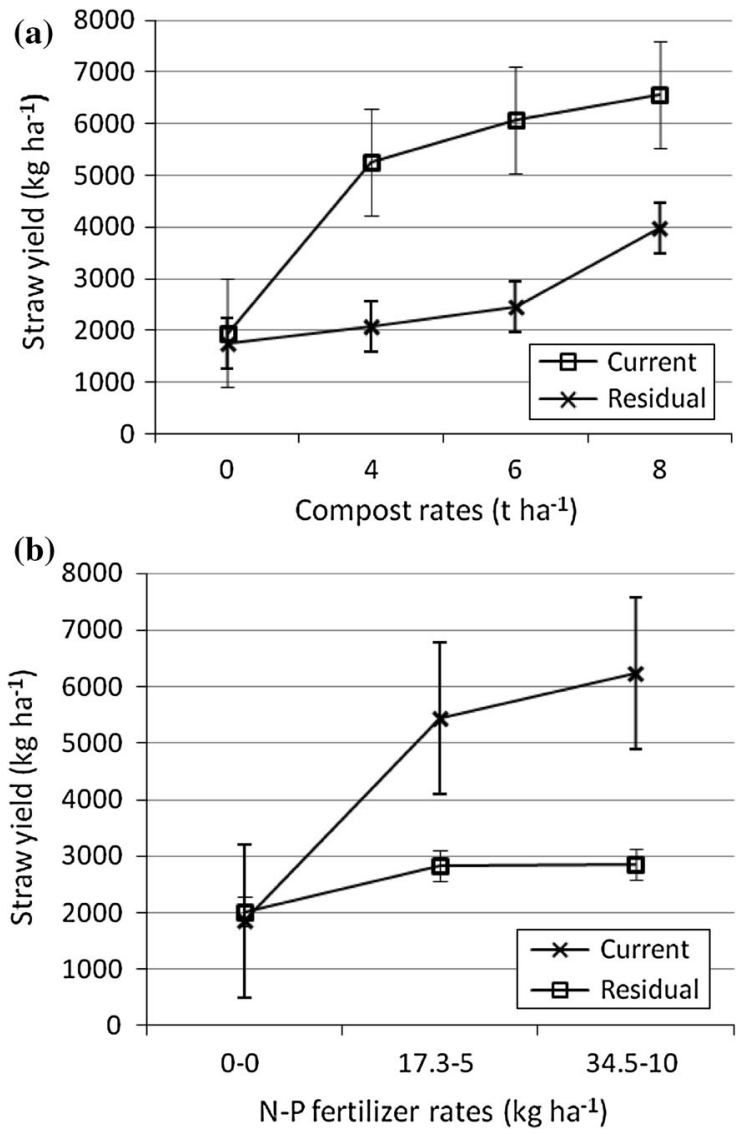

Fig. 2 Current and residual effects of compost (a) and inorganic fertilizers (b) on mean wheat straw yield at the GumaraMaksegnit watershed. Vertical bars represent \pm SE

effects trial (Fig. 4c). CEC was significantly higher in the current trial when applying $8 \mathrm{t}$ compost ha ${ }^{-1}$ and 6 and $8 \mathrm{t}$ compost $\mathrm{ha}^{-1}$ in the residual effects trial (Fig. 4d). In the current effect trial, applying 4, 6 and $8 \mathrm{t}$ compost $\mathrm{ha}^{-1}$ increased available $\mathrm{P}$ content by 

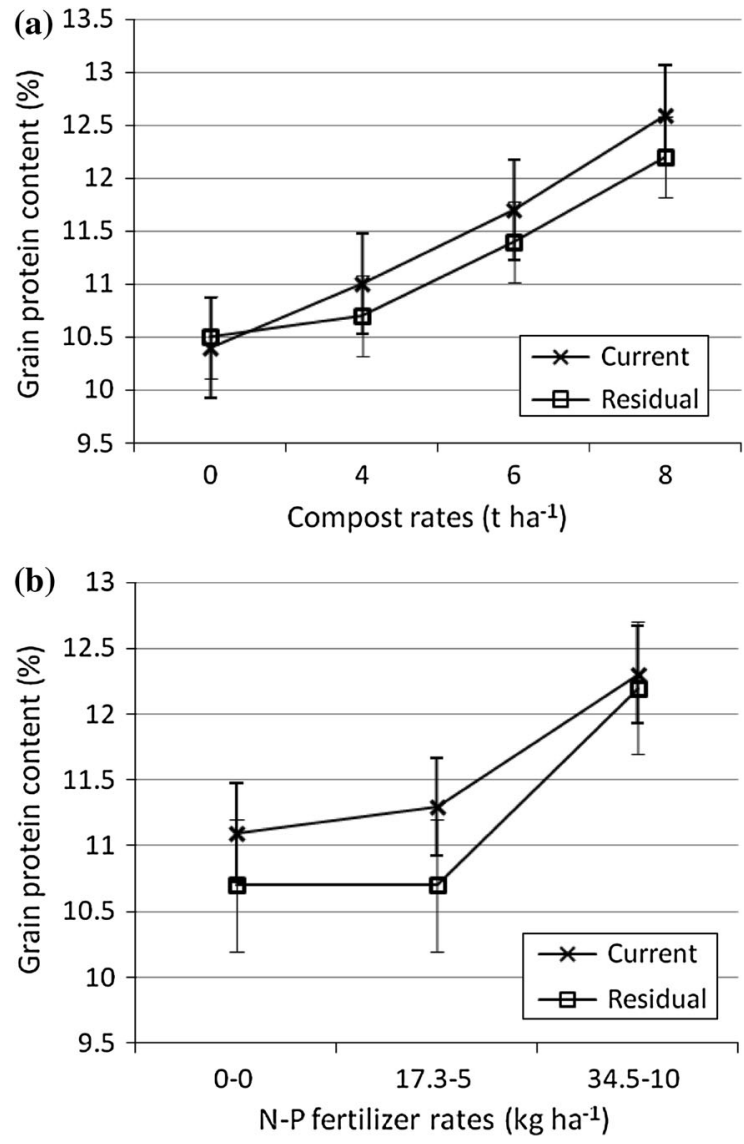

Fig. 3 Current and residual effects of compost (a) and inorganic fertilizers (b) on mean wheat grain protein content at the Gumara-Maksegnit watershed. Vertical bars represent $\pm \mathrm{SE}$

$89-161 \%$, organic matter content by $84-108 \%$, exchangeable $\mathrm{Ca}$ content by $5-17 \%$, and $C E C$ by 9-15\% over the plot with no compost. Similarly, for the same compost application rates in the residual effects trial, available $\mathrm{P}$ increased by $138-173 \%$, organic matter by $79-104 \%$, exchangeable $\mathrm{Ca}$ by $4-17 \%$ and $C E C$ by $11-17 \%$.

Economic analysis

The partial budget analysis showed that treatment combination $6 \mathrm{t} \mathrm{ha}^{-1}$ compost and $34.5-10 \mathrm{~kg} \mathrm{~N}-\mathrm{P}$ $\mathrm{ha}^{-1}$ is economically profitable as it gives a rate of return above the $100 \%$ acceptable rate of return. Although the highest MRR (1,732\%) was recorded for the treatment combination $4 \mathrm{t} \mathrm{ha}^{-1}$ compost and $17.3-5 \mathrm{~kg} \mathrm{~N}-\mathrm{P} \mathrm{ha}{ }^{-1}$, farmers' overall net income could improve if an additional investment is made further to applying $6 \mathrm{t} \mathrm{ha}^{-1}$ compost and 34.5-10 kg N-P ha with MRR of $844 \%$ (Table 3). The calculated MRR tells that by using this combination of fertilizers, farmers can get a return of US $\$ 8.44$ for every US $\$ 1.0$ of additional investment on organic and inorganic fertilizers. The economic analysis result agrees with the agronomic result.

\section{Discussions}

Grain and straw yields

Compost application is reported to have positive effect on the physicochemical and biological properties of the soil which often leads to higher crop growth and yield (Abedi et al. 2010; Hafidi et al. 2012). Compost provides a steady supply of nutrients to the crop, thus improving productivity (Hafidi et al. 2012). In our study, grain yield increased significantly by the application of compost together with inorganic fertilizers. Applying 6 t compost ha ${ }^{-1}$ with $34.5-10 \mathrm{~kg} \mathrm{~N}-$ $\mathrm{P} \mathrm{ha}^{-1}$ gave a yield increase of $521 \%$ over the control, and the application of $8 \mathrm{t}$ compost $\mathrm{ha}^{-1}$ with $34.5-10 \mathrm{~kg} \mathrm{~N}-\mathrm{P} \mathrm{ha}^{-1}$ gave a yield increase of $442 \%$. The residual effect from 1 year application of compost and inorganic fertilizers also gave yield benefits ranging from 7 to $271 \%$. This indicates that farmers who cannot afford to apply compost every year could improve productivity by as much as $271 \%$ by applying compost every other year. These results are in agreement with other reports on rice (Sarwar et al. 2007), wheat (Sarwar et al. 2007; Abedi et al. 2010) and sorghum (Ouedraogo et al. 2001). Nahar et al. (1995) reported $97 \%$ yield increase in wheat from residual effects of compost.

Wheat straw yield increased by 169-236 \% when the compost was applied and by $19-128 \%$ in the following season, due to the residual effects of compost. Straw yield also increased 193-237\% in the current and $40 \%$ in the residual season, respectively, as a response to inorganic fertilizer application. Similar results, where significant increase in rice and wheat straw due to the combined application of 12 and $24 \mathrm{t}$ compost ha ${ }^{-1}$, respectively, and N, P, K fertilizers were reported by Sarwar et al. (2007). Wheat straw is an important dry season livestock feed in the watershed. Thus, the observed increase in straw yield 
Fig. 4 Current and residual effects of compost on mean soil available $\mathrm{P}(\mathbf{a})$, organic matter content $(\mathbf{b})$, and exchangeable $\mathrm{Ca}(\mathbf{c})$ content and CEC (d) at GumaraMaksegnit watershed. Vertical bars represent $\pm \mathrm{SE}$
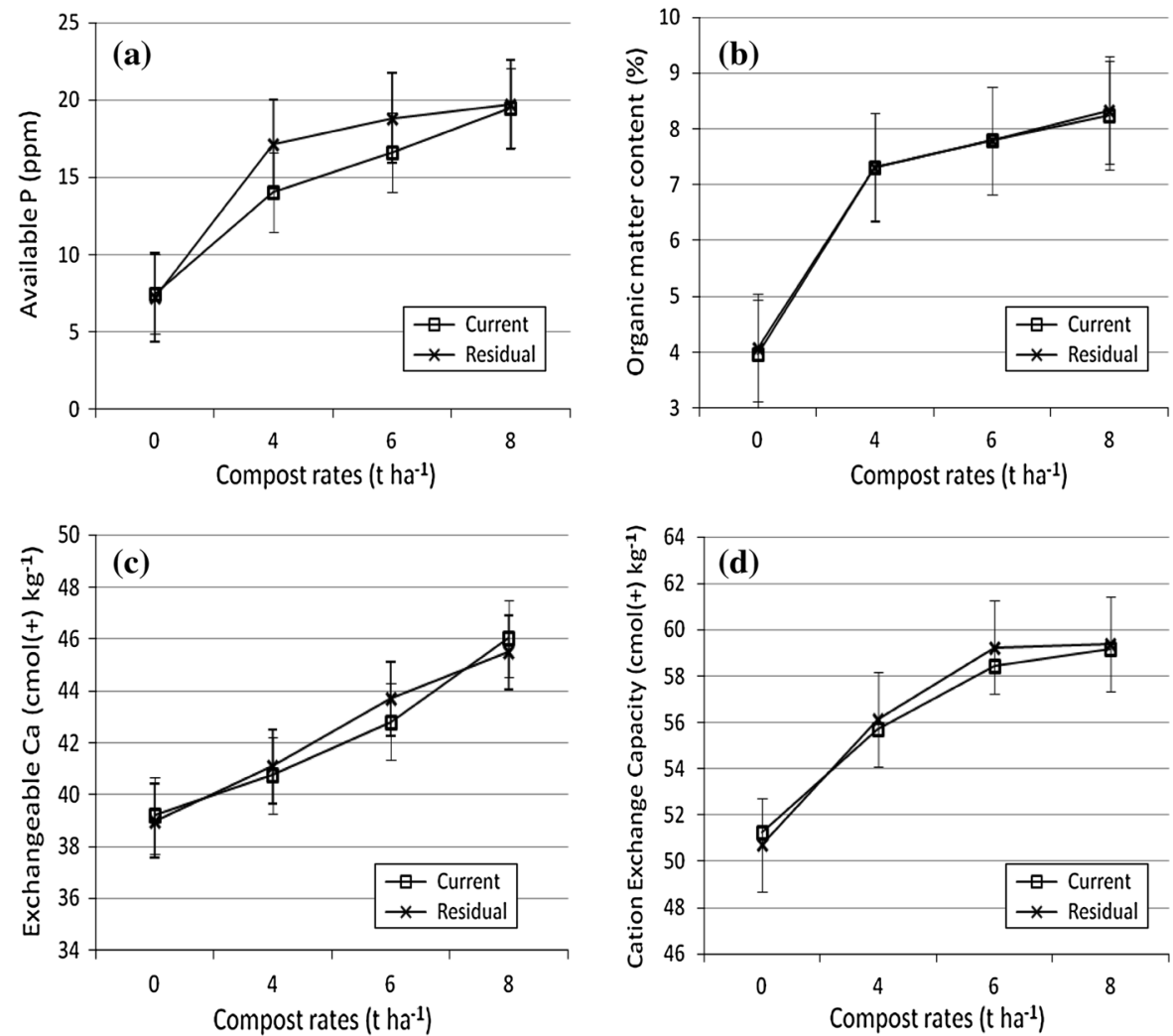

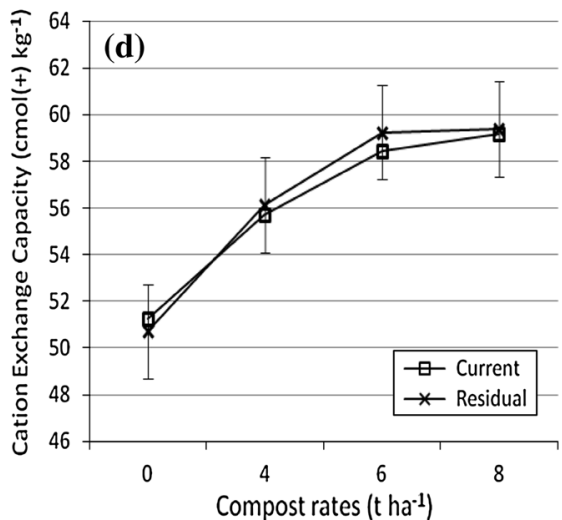

Table 3 Economic analysis for the use of compost and inorganic fertilizer on bread wheat in the Gumara-Maksegnit watershed

\begin{tabular}{|c|c|c|c|c|c|c|c|c|c|c|}
\hline $\begin{array}{l}\text { Compost } \\
\left(\mathrm{t} \mathrm{ha}{ }^{-1}\right)\end{array}$ & $\begin{array}{l}\mathrm{N}-\mathrm{P} \\
\text { fertilizer } \\
\left(\mathrm{kg} \mathrm{ha}^{-1}\right)\end{array}$ & $\begin{array}{l}\text { Grain } \\
\text { yield } \\
\left(\mathrm{kg} \mathrm{ha}^{-1}\right)\end{array}$ & $\begin{array}{l}\text { Straw } \\
\text { yield } \\
\left.(\mathrm{t} \mathrm{ha})^{-1}\right)\end{array}$ & $\begin{array}{l}\text { Adjusted } \\
\text { grain } \\
\text { yield } \\
\left(\mathrm{kg} \mathrm{ha}^{-1}\right)\end{array}$ & $\begin{array}{l}\text { Adjusted } \\
\text { straw } \\
\text { yield } \\
\left(\mathrm{t} \mathrm{ha}^{-1}\right)\end{array}$ & $\begin{array}{l}\text { Gross field } \\
\text { benefits } \\
\left(\text { US } \$ h^{-1}\right)\end{array}$ & $\begin{array}{l}\text { Total cost } \\
\text { that vary } \\
\left(\mathrm{US} \$ \mathrm{ha}^{-1}\right)\end{array}$ & $\begin{array}{l}\text { Net benefit } \\
\left(\mathrm{US} \$ \mathrm{ha}^{-1}\right)\end{array}$ & Dominance & $\mathrm{MRR}^{\mathrm{a}}$ \\
\hline 0 & $0-0$ & 604 & 1.9 & 543.6 & 1.71 & 246.4 & 0.00 & 246.42 & & \\
\hline 0 & $17.3-5$ & 1,233 & 2.1 & $1,109.7$ & 1.89 & 501.3 & 37.70 & 463.65 & & 576 \\
\hline 4 & $0-0$ & 1,514 & 2.6 & $1,362.6$ & 2.34 & 615.6 & 61.04 & 554.59 & & 390 \\
\hline 0 & $34.5-10$ & 1,538 & 2.7 & $1,384.2$ & 2.43 & 625.4 & 74.75 & 550.69 & $\mathrm{D}$ & \\
\hline 6 & $0-0$ & 2,057 & 2.7 & $1,851.3$ & 2.43 & 835.6 & 91.56 & 744.08 & & 621 \\
\hline 4 & $17.3-5$ & 2,381 & 3 & $2,142.9$ & 2.7 & 967.1 & 98.74 & 868.40 & & 1,732 \\
\hline 8 & $0-0$ & 2,727 & 3.6 & $2,454.3$ & 3.24 & $1,107.8$ & 122.08 & 985.76 & & 503 \\
\hline 6 & $17.3-5$ & 2,576 & 3.6 & $2,318.4$ & 3.24 & $1,046.7$ & 129.26 & 917.42 & $\mathrm{D}$ & \\
\hline 4 & $34.5-10$ & 2,587 & 5.3 & $2,328.3$ & 4.77 & $1,052.7$ & 135.79 & 916.95 & $\mathrm{D}$ & \\
\hline 8 & $17.3-5$ & 2,707 & 3.8 & $2,436.3$ & 3.42 & 1,099.9 & 159.78 & 940.15 & $\mathrm{D}$ & \\
\hline 6 & $34.5-10$ & 3,752 & 6.1 & $3,376.8$ & 5.49 & $1,525.3$ & 166.31 & $1,359.01$ & & 844 \\
\hline 8 & $34.5-10$ & 3,279 & 6.6 & $2,951.1$ & 5.94 & $1,334.2$ & 196.83 & $1,137.40$ & $\mathrm{D}$ & \\
\hline
\end{tabular}

a Marginal rate of return

has implication on livestock feed availability and livestock productivity by ensuring a higher supply of feed. The extra straw achieved as a result of compost application could also be used either for soil application to maintain the organic matter content or could be sold to generate income. 
Increase in grain and straw yields from the combined application of compost and inorganic fertilizers could be attributed to better crop growth, due to the readily available nutrients from the inorganic fertilizer sources and the improved nutrient availability and controlled release of nutrients from the compost (Seran et al. 2010; Suge et al. 2011). Compost application, besides improving the physico-chemical properties of the soil, slowly releases nutrients and prevents nutrient losses from the inorganic fertilizers by binding to nutrients and releasing them with time (Arshad et al. 2004; Abedi et al. 2010). Consequently, the combined use of organic fertilizers with inorganic fertilizers improves inorganic fertilizer use efficiency and thus reduce the amount of inorganic fertilizer required (Bayu et al. 2006a; Abedi et al. 2010; Tilahun-Tadesse et al. 2013). The increase in yield could be attributed to better root development and nutrient uptake resulting from improved soil structure due to compost effects. Also the positive effects of compost in preventing the lose of nutrients from chemical fertilizers and promoting a slow nutrient release with the passage of time could result in higher crop yields (Arshad et al. 2004; Abedi et al. 2010). Several reseachers (Bayu et al. 2006b; Abedi et al. 2010; Tilahun-Tadesse et al. 2013) have reported that organic inputs have improved the physical properties of the soil which would have caused increased root development and thus increased nutrient and water uptake.

\section{Grain protein content}

It is widely reported that protein content in wheat grain, which is strongly associated with bread-making quality, often improves with sufficient nutrient supply (Takahashi et al. 2006; Abedi et al. 2010). In this study grain protein content has significantly increased with the compost and inorganic fertilizers application. Grain protein content increased 21 and $16 \%$ with the current and residual effects, respectively, of $8 \mathrm{t}$ compost $\mathrm{ha}^{-1}$. Similarly, grain protein content increased 11 and $14 \%$ with the current and residual effects, respectively, of 34.5-10 kg N-P ha ${ }^{-1}$. Similar to these results, Abedi et al. (2010) reported increase in wheat grain protein content in response to applying $6 \mathrm{t}$ compost ha ${ }^{-1}$. Hossain et al. (2012) also reported a significantly higher grain protein $(10.08 \%)$ in maize from applying $22.5 \mathrm{t}$ compost $\mathrm{ha}^{-1}$ and $\mathrm{N}-\mathrm{P}-\mathrm{K}$
(30-15-20 $\mathrm{kg} \mathrm{ha}^{-1}$ ), respectively as compared to the protein content in the control $(4.85 \%)$. The increase in grain protein content with compost and inorganic fertilizer application could be ascribed to more nutrient availability and increased nutrient uptake as a result of improved soil structure (Abedi et al. 2010). In countries where cereal grains are the major source of protein for human consumption, increase in grain protein content by improving soil fertility could be taken as a least-cost approach to improve human nutrition.

\section{Soil chemical properties}

Compost addition to soil has long been considered important in maintaining the quality of the soil, basically in terms of improving its physical, chemical and biological properties (Sarwar et al. 2008; Hepperly et al. 2009; Hafidi et al. 2012). In our study, the current and residual effects of compost have improved many soil chemical properties. Soil organic matter (SOM), regarded as a key factor in determining soil fertility and productivity, increased $108 \%$ in the current and $104 \%$ in the residual effect, respectively, of $8 \mathrm{t}$ compost $\mathrm{ha}^{-1}$. Several research reports have shown improvement in the SOM content with organic fertilizer application. In a rice-wheat rotation Sarwar et al. (2008) reported a rise in SOM content from 0.56 to $0.98 \%$ after rice and from 0.67 to $1.30 \%$ after wheat with the application of $24 \mathrm{t}$ compost ha ${ }^{-1}$ with a recommended fertilizer rate $\left(100-70-70 \mathrm{~kg} \mathrm{ha}^{-1} \mathrm{~N}-\right.$ $\mathrm{P}-\mathrm{K})$. Reeve et al. (2012) reported a 1.6-fold higher total organic C (1.43 vs. $0.89 \%, p<0.002)$, in a soil that was amended with compost 16 years before, compared to a soil that was not amended. Increase in SOM as a result of compost application has great implication in terms of improving soil productivity as SOM is the ultimate source of nutrients and microbial activity in the soil. SOM also has a major role in improving soil structure, water holding capacity, infiltration rate, aeration and porosity of the soil as well as reducing environmental pollution due to the carbon sequestration effect (Sarwar et al. 2008).

Compost contains macro and micro nutrients (Eyheraguibel et al. 2008; Hafidi et al. 2012). Several studies (Abedi et al. 2010; Hafidi et al. 2012) have shown that humic substances in compost enhance the availability of macro and micro nutrients $(\mathrm{N}, \mathrm{P}, \mathrm{K}, \mathrm{Mg}$, and $\mathrm{Ca}$ ). In our study, available soil P increased $162 \%$ in the current trial and $173 \%$ in the residual effect 
trial, respectively, due to the application of $8 \mathrm{t}$ compost ha ${ }^{-1}$. Similar results were reported by Sarwar et al. (2008) who reported an increase in available $\mathrm{P}$ from $5.72 \mathrm{mg} \mathrm{kg}^{-1}$ in the control to $27.55 \mathrm{mg} \mathrm{kg}^{-1}$ with the application of $24 \mathrm{t}$ compost $\mathrm{ha}^{-1}$ and $100-70-70 \mathrm{~kg} \mathrm{~N}-\mathrm{P}-\mathrm{K} \mathrm{ha}^{-1}$. The increase in available P could be, according to Singh et al. (2008), due to the addition of $P$ through compost in excess of removal by the crop. It could also be due to the fact that organic manures, on decomposition, solubilize insoluble organic P fractions through release of various organic acids, thus resulting in a significant improvement in soil available P content (Sharma et al., 2013). In this study, exchangeable $\mathrm{Ca}$ content increased $16.7 \%$ in the current trial and $17.4 \%$ in the residual effect trial, respectively, due to the application of $8 \mathrm{t}$ compost $\mathrm{ha}^{-1}$. In agreement to this result, Hafidi et al. (2012) reported an increase in $\mathrm{Ca}$ content from 1,399.7 to $2,109.9 \mathrm{mg} \mathrm{kg}^{-1}$ with the application of $28 \mathrm{t}$ compost $\mathrm{ha}^{-1}$. They also reported an increase in the levels of saturation of other alkaline elements $(\mathrm{K}, \mathrm{Na})$ with the application of 28 and $42 \mathrm{t}$ compost $\mathrm{ha}^{-1}$, effect that was not observed in this study. According to Sarwar et al. (2008) the increase in $\mathrm{Ca}$ and $\mathrm{Mg}$ with compost application could be due to the reaction of organic acids with $\mathrm{CaCO}_{3}$ and $\mathrm{Mg}$ salts. The increase could also be from the addition of $\mathrm{Ca}$ from the compost itself as it has high content of $\mathrm{Ca}$ (Table 1).

Cation exchange capacity is a key soil chemical property characterizing the adsorption capacity of a soil. Increase in the soil CEC implies that the soil will be able to retain nutrients in the soil-plant system in larger quantities and for longer time. Hence the crop will utilize nutrients more effectively, while reducing nutrient loss by leaching. In this study, $C E C$ of the soil increased $15.4 \%$ in the current trial and $17.1 \%$ in the residual effect trial, respectively, due to the application of $8 \mathrm{t}$ compost $\mathrm{ha}^{-1}$. In line with this result, Ouedraogo et al. (2001) reported a significant increase in $C E C$ with the application of $10 \mathrm{tha}^{-1}$ compost in Burkina Faso. Hafidi et al. (2012) have shown an increase in $C E C$ from $35.6 \mathrm{meq} / 100 \mathrm{~g}$ in the control plot to $46.8 \mathrm{meq} / 100 \mathrm{~g}, 46.9 \mathrm{meq} / 100 \mathrm{~g}$ and $47.2 \mathrm{meq} /$ $100 \mathrm{~g}$ by applying 14, 28 and $42 \mathrm{t}$ compost $\mathrm{ha}^{-1}$, respectively. The increase in $C E C$ with compost application could be attributed to an increase in soil organic matter content (Ouedraogo et al. 2001).

The observed increase in the nutrient contents of the soil in the residual plots in this study could be due to the fact that nutrients contained in compost are stored for longer time in the soil and are released more slowly, thereby ensuring a long residual effect (Sharma and Mittra 1991) and to solubilisation of nutrients from soil minerals due to the effect of compost's organic acids (Sharma et al. 2013).

\section{Economic analysis}

Financial profitability is the ultimate measure to recommend a technology. Any technology that is agronomically feasible and is beneficial for soil improvement would not be attractive to farmers unless it is financially profitable. In the current study, by applying $6 \mathrm{t}$ compost ha ${ }^{-1}$ with $34.5-10 \mathrm{~kg} \mathrm{~N}-\mathrm{P} \mathrm{ha}^{-1}$ farmers in the watershed will be able to gain US $\$ 8.44$ for each US\$1.0 investment, which implies a very high increase in farmers' income with a simple improvement in soil fertility management. This financial benefit is in addition to the benefit in terms of soil improvement which we could not quantify in terms of monetary value.

\section{Conclusions}

Using compost for soil quality and productivity improvement has been receiving much attention by the government of Ethiopia. In this study, it was found that the combined use of compost and inorganic fertilizers improve the overall soil fertility and wheat productivity. Generally, soil quality and productivity may be more sustainable with the integrated application of compost and inorganic fertilizers than with the use of inorganic fertilizers alone. From the results of the current experiment, it could be concluded that combined applications of $6 \mathrm{t}$ compost $\mathrm{ha}^{-1}$ with $34.5-10 \mathrm{~kg} \mathrm{~N}-\mathrm{P} \mathrm{ha}{ }^{-1}$ resulted in improvement of most soil physicochemical properties and yield and grain quality of wheat over 2 years. This implies that by combining compost with inorganic fertilizers farmers would be able to reduce the inorganic fertilizer requirement by $50 \%$. With these rates of compost and inorganic fertilizer application in the previous year farmers could get a yield benefit as much as $271 \%$ without any compost and inorganic fertilizer application in the current year. The combined use of compost and inorganic fertilizers, therefore, is a viable technology to combat soil degradation and to increase 
productivity. However, despite the short term benefits recorded in this study, the viability of using compost in crop production will depend on the willingness and interest of farmers in producing compost. Extensive demonstration and training is required to show farmers the agronomic importance and economic value of compost application on improving the productivity of their soils.

\section{References}

Abedi T, Alemzadeh A, KazemeIni SA (2010) Effect of organic and inorganic fertilizers on grain yield and protein banding pattern of wheat. Aust J Crop Sci 4:384-389

Arshad M, Khalid A, Mahmood MH, Zahir ZA (2004) Potential of nitrogen and L-tryptophan enriched compost for improving growth and yield of hybrid maize. Pak J Agric Sci 41:16-24

Ayuk ET (2001) Social, economic and policy dimensions of soil organic matter management in Sub-Saharan Africa: challenges and opportunities. Nutr Cycl Agroecosyst 61:183-195

Bationo A, Lompo F, Koala S (1998) Research on nutrient flows and balances in West Africa: state-of-the-art. Agric Ecosyst Environ 71:19-35

Bationo A, Kihara J, Vanlauwe B, Waswa B, Kimetu J (2007) Soil organic carbon dynamics, functions and management in West African agro-ecosystems. Agric Syst 94:13-25

Bayu W, Rethman NFG, Hammes PS, Alemu G (2006a) Effects of farmyard manure and inorganic fertilizers on sorghum growth, yield, and nitrogen use in a semi-arid area of Ethiopia. J Plant Nutr 29:391-407

Bayu W, Rethman NFG, Hammes PS, Alemu G (2006b) Application of farmyard manure improved the chemical and physical properties of the soil in a semi-arid area in Ethiopia. Biol Agric Hortic 24:293-300

CIMMYT (International Maize and Wheat Improvement Centre) (1988) From agronomic data to farmer recommendation: an economics training manual completely revised edition. CIMMYT, Mexico

Eyheraguibel B, Silvestre J, Morard P (2008) Effects of humic substances derived from organic waste enhancement on the growth and mineral nutrition of maize. Bioresour Technol 99:4206-4212

Hafidi M, Amir S, Meddich A, Jouraiphy A, Winterton P, El Gharous M, Duponnois R (2012) Impact of applying composted biosolids on wheat growth and yield parameters on a calcimagnesic soil in a semi-arid region. Afr J Biotechnol 11:9805-9815

Hepperly P, Lotter D, Ulsh CZ, Seidel R, Reider C (2009) Compost, manure and synthetic fertilizer influences crop yields, soil properties, nitrate leaching and crop nutrient content. Compost Sci Util 17:117-126

Hossain N, Kibria MG, Osman KT (2012) Mineral nutrition and quality of maiz (Zea Mays L.) as affected by household waste compost, poultry manure and inorganic fertilizers IOSR. J Pharm Biol Sci 3:44-52

Jackson ML (1958) Soil chemical analysis. Prentice Hall of India, New Delhi

Lakew D, Menale K, Benin S, Pender J (2000) Land degradation and strategies for sustainable development in the Ethiopian highlands: Amhara Region. Socio-economics and policy research working paper 32. ILRI (International Livestock Research Institute), Nairobi, Kenya. p 122

Nahar K, Haider J, Karim AJMS (1995) Residual effect of organic manures and influence of nitrogen fertilizer on soil properties and performance of wheat. Ann Bangl Agric 5:73-78

NMSA (National Meteorological Service Agency) (2009) Climate and agro-climate resource of Ethiopia. National Meteorological Service Agency, Bahir Dar

Olsen SR, Cole CV, Watanabe FS, Dean LA (1954) Estimation of available phosphorus in soils by extraction with sodium bicarbonate. USDA Circular No 939:1-19

Ouedraogo E, Mando A, Zombre NP (2001) Use of compost to improve soil properties and crop productivity under low input agricultural system in West Africa. Agric Ecosys Environ 84:259-266

Page AL, Miller RH, Keeney DR (1982) Methods of soil analysis. Part 2. Chemical and microbiological properties, 2nd edn. Soil Science Society of America, Madison

Reeve JR, Endelman JB, Miller BE, Hole DJ (2012) Residual effects of compost on soil quality and dryland wheat yield sixteen years after compost application. Soil Sci Soc Amer J 76(1):278-285

Sahilemedin S, Taye B (2000) Procedure for soil and plant analysis. National Soil Research Center, Ethiopian Agricultural Research Organization, Addis Abeba

Sanchez AP, Leakey RRB (1997) Land use transformation in Africa: three determinants for balancing food security with natural resource utilization. Europ J Agron 7:5-23

Sanchez AP, Shepherd KD, Soule MJ, Buresh RJ, Izac AMN (1997) Soil fertility replenishment in Africa: an investment in natural resource capital. In: Buresh RJ, Sanchez AP, Calhoun F (eds) Replenishing soil fertility in Africa. SSSA Special publication No. 51, Madison, pp 1-46

Sarwar G, Hussain N, Schmeisky H, Muhammad S (2007) Use of compost an environment friendly technology for enhancing rice-wheat production in Pakistan. Pak J Bot 39:1553-1558

Sarwar G, Schmeisky H, Hussain N, Muhammad S, Ibrahim M, Safdar E (2008) Improvement of soil physical and chemical improvement with compost application in rice-wheat cropping system. Pak J Bot 40:275-282

Seran TH, Srikrishnah S, Ahamed MMZ (2010) Effect of different levels of inorganic fertilizers and compost as basal application on the growth and yield of onion (Allium cepa L.). J Agric Sci 5:64-70

Sharma AR, Mittra BN (1991) Effect of different rates of application of organic and nitrogen fertilizers in a ricebased cropping system. J Agric Sci 117:313-318

Sharma GD, Thakur R, Som R, Kauraw DL, Kulhare PS (2013) Impact of integrated nutrient management on yield, nutrient uptake, protein content of wheat (Triticum astivam) and soil fertility in Typic Haplustert. Bioscan 8:1159-1160 
Singh F, Kumar R, Pal S (2008) Integrated nutrient management in rice-wheat cropping system for sustainable productivity. J Indian Soc Soil Sci 56:205-208

Solomon D, Fritzsche F, Tekalign M, Lehmann J, Zech W (2002) Soil organic matter composition in the Subhumid Ethiopian highlands as influenced by deforestation and agricultural management. Soil Sci Soc Am J 66:68-82

Stoorvogel JJ, Smaling EMA, Janssen BH (1993) Calculating soil nutrient balances in Africa at different scales: i Supranational scale. Fertil Res 35:227-235

Suge JK, Omunyin ME, Omami EN (2011) Effect of organic and inorganic sources of fertilizer on growth, yield and fruit quality of eggplant (Solanum Melongena L). Arch Appl Sci Res 3(6):470-479

Takahashi S, Anwar MR, de Vera SG (2006) Effects of compost and nitrogen fertilizer on wheat nitrogen use in Japanese soils. Agron J 99:1151-1157
Tilahun A (2003) Opportunities and challenges in reversing land degradation: the regional experience. In: Amede T (ed) Natural resources degradation and environmental concerns in the Amhara National Regional State: impact on food security. Ethiopian Soil Science Society, Ethiopian, pp 173-183

Tilahun-Tadesse F, Nigussie-Dechassa R, Wondimu B, Setegn G (2013) Effect of farmyard manure and inorganic fertilizers on the growth, yield and moisture stress tolerance of rain-fed lowland rice. Am J Res Com 1:275-301

Tisdale SL, Nelson WL, Beaton JD, Havlin JL (1993) Soil fertility and fertilizers, 5th edn. Macmillan Publishing Company, USA

Voortman RL, Sonneveld BG, Keyzer MA (2000) African land ecology: Opportunities and constraints for agricultural development. Center for international development working paper 37. Cambridge, Mass, USA 